\title{
ハンマーヘッド型リボザイムー金属イオン相互作用の分光学的解析
}

\author{
田中好幸
}

\section{Spectroscopic Analyses of the Interaction between Hammerhead Ribozymes and Metal Ions}

\author{
Yoshiyuki TANAKA \\ Laboratory of Molecular Transformation, Tohoku University Graduate School of Pharmaceutical \\ Sciences, Aobayama, Aoba-ku, Sendai 980-8578, Japan
}

(Received February 6, 2003)

\begin{abstract}
Biologically active RNA molecules utilize metal ions to fold into specific conformations or to form a catalytic center. Hammerhead ribozymes also contain a metal ion-binding motif in their conserved core region. This motif and bound metal ions have recently been focused on from the viewpoint of whether the metal ions are a catalytic metal or a structural metal. We studied the interaction between metal ions and an RNA oligomer, r (GGACGAGUCC), which mimics the metal ion-binding motif of hammerhead ribozymes, using NMR spectroscopy in solution. Using ${ }^{15} \mathrm{~N}$-labeled RNA oligomers, the chemical shift of N7 of the G7 residue $[N 7(G 7)]$ in the metal ion-binding motif was specifically perturbed upon the addition of $\mathrm{Cd}$ (II). It was also found that the ${ }^{31} \mathrm{P}$ resonance of the phosphate of the A9 residue showed the largest perturbation of all the ${ }^{31} \mathrm{P}$ resonances during titration. These data indicate that divalent cations can bind to the metal ion-binding motif in solution, and that the binding sites for cations are N7 (G7) and the phosphate of A9. More importantly, the metal ion-binding motif is an independent functional module that can capture divalent cations without the assistance of other conserved residues in hammerhead ribozymes.
\end{abstract}

Key words_-RNA; metal; interaction; NMR; ribozyme

\section{1. はじめに}

核酸はタンパク質と並び，生体を構成する重要な 因子である。中でも RNA 分子は DNA の遺伝情報 が蛋白質に変換される際の媒体としてのみでなく, RNA 分子自身が積極的に機能を担っていることが 分かってきている. テトラヒメナ（tetrahymena） のグループI イントロン（group I intron）が RNA 鎖の部位特異的切断及び結合反応を触媒しているこ とが発見されて以来, RNA 分子はタンパク質同様 に酵素活性を有する分子として注目されるようにな

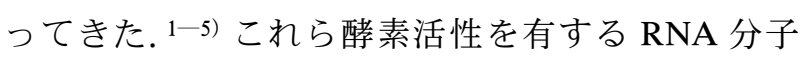
はリボザイム（Ribonucleic Acid + Enzyme : Ribozyme）と総称されており，上記以外にもハンマー ヘッド型リボザイム, ${ }^{4)}$ ヘアピン型リボザイム ${ }^{5)}$

東北大学大学院薬学研究科 - 分子変換化学分野 (下980 -8578 仙台市青葉区荒巻字青葉)

e-mail: tanaka@mail.pharm.tohoku.ac.jp

*本総説は, 平成 14 年度日本薬学会東北支部学術奨励 賞の受賞を記念して記述したものである.
どが知られている。これらの中でハンマーヘッド型 リボザイムは最も分子量が小さく, RNA 分子によ る RNA 鎖切断反応のメカニズム解明に適した分子 である。加えて遺伝子治療薬としての応用6,7) も期 待される分子で, その酵素活性発現のメカニズムの 解明が望まれている.

ハンマーヘッド型リボザイムは基質 RNA 鎖を塩 基対形成により認識し, 部位特異的に切断する RNA 酵素である (Fig. 1)。二次構造が金桘型をし ていたことからこのように命名された（以下本稿で は, ハンマーヘッド型リボザイムを単にリボザイム と呼ぶことにする)。リボザイムは二価金属イオン を補因子として有しており, 生理条件下では二価金 属イオンが活性種本体であることが示されてい る. ${ }^{8)}$ リボザイムの結晶構造解析の結果から, 多く の結晶構造中で金属イオンの結合が見られた塩基配 列がある（Fig. 1).9-12) この配列がリボザイムの保 存配列の中に含まれていたことから, 切断活性を担 う触媒金属であるかどうかが検討されている金属个 
(a)

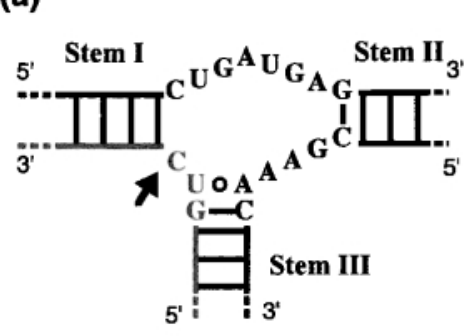

\section{Secondary structure \\ (Hammerhead ribozyme \& Substrate)}

(b)

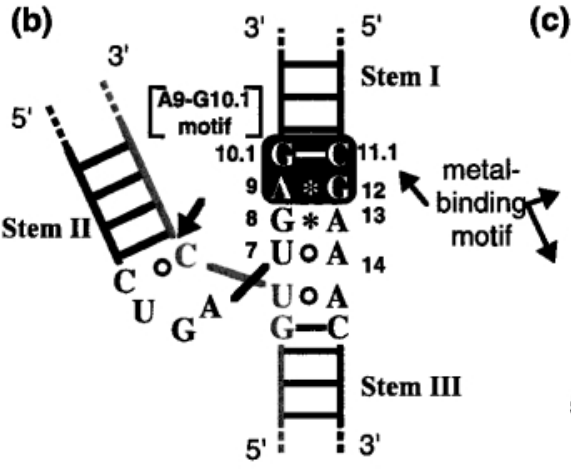

Topology

(Hammerhead ribozyme \& Substrate) (c)

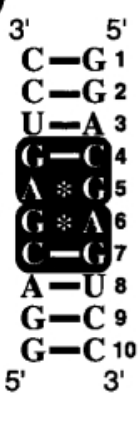

GA10 (d)

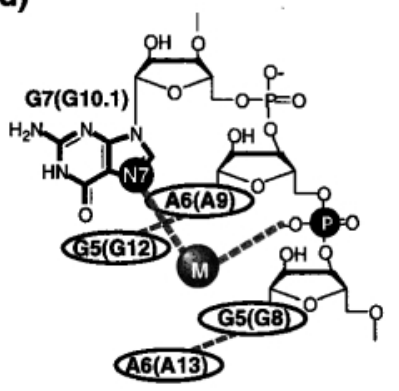

Common metal ionbinding motif (A9/G10.1 site)

Fig. 1. Schematic Representations of Secondary Structures of Hammerhead Ribozymes and GA10, and the Metal Ion-Binding Motif

(a) Conserved sequences and the secondary structure of hammerhead ribozymes. (b) The topology of hammerhead ribozymes based on the crystal structures with numbering systems. (c) GA10 with numbering systems. (d) Schematic representation of the metal ion-binding motif (the A9/G10.1 site) of hammerhead ribozymes. The residue numbers in GA10 are shown, and the residue numbers in hammerhead ribozyme are also shown in parenthesis. In (b) and (c), the metal-binding motif (the A9/G10.1 site) in hammerhead ribozymes and GA10 is highlighted. In (a) and (b), enzyme and substrate strands are shown in black and gray, respectively, and the cleavage site is indicated by a black arrow. In (d), a metal ion is shown in a gray ball with a character "M", and is linked to binding sites via dashed lines. The tandem G-A pairs are indicated by black dashed lines with residue names. Watson-Crick base-pairs, non-Watson-Crick base-pairs, and sheared-type G -A pairs are indicated in bars, open circles and asterisks. Putative metal ion-binding sites (N7 of G7, and the phosphate of A9) are highlighted.

オン結合モチーフである.13-19) したがって, 本研 究ではこの金属イオン結合モチーフと二価金属イオ ンとの相互作用を NMR を用いて解析した. ${ }^{20-21)}$

\section{2. 金属イオン結合モチーフ}

リボザイムの金属イオン結合モチーフは X 線結 晶構造解析により見つかったものであり,この部位 への金属イオンの結合がリボザイムの結晶中で最も 保存されている (Fig. 1). 9-12)このモチーフはハン マーヘッド型リボザイムのステム II の G10.1C11.1 塩基対とそれに隣接するコア領域（保存度の 高い塩基が集中しているループ領域）中の連続する $\mathrm{A}-\mathrm{G}$ ミスマッチ（A9-G12, G8-A13 塩基対）より 形成されている（Fig. 1)。このモチーフ内の塩基 に対して塩基置換や化学修飾等の変異をいれると活 性が大きく落ちることが知られている. ${ }^{13-19,22-26)}$ さらにこのモチーフに対して二価金属イオンが結合 するに従って, リボザイム活性が上昇することが速 度論解析の結果より示されている. これら結果に基 づき，金属イオン結合モチーフに結合した金属イオ ンが, RNA 鎖の切断に直接関与する金属イオン (触媒金属) であるという説16) と，そうではなく構 造形成に必要な金属イオン（構造金属）であるとい う 2 つの説19)が存在し, このモチーフと金属イオン の相互作用を解析することが, メカニズム解明に必 須のステップとなっている.

ここまで金属イオンが核酸に結合すると言う漠然
とした言い方をしてきたが, 金属イオンの核酸に対 する結合を配位化学の観点からとらえ直してみた い. 一般に金属イオンは水溶液中では, 配位結合あ るいは単に静電相互作用により水分子に取り囲まれ ている. 中でも二価金属イオンの一次水和水は金属 イオンに対して配位していると考えられる。したが つて金属イオンが核酸の特定の官能基に対して結合 するといった場合には，これらの配位子を介した （水素結合と静電相互作用による）結合（outersphere binding）と, 配位子を介さない金属核と官 能基間の配位結合（inner-sphere coordination）の 2 種類が存在する（Fig. 2)。配位子を介した結合の 場合，金属配位子と核酸官能基間で水素結合のプロ トン供与基と受容基が立体構造的に対合する必要が あり, 配位結合の場合, 金属イオンの配位水をはぎ 取って核酸官能基が代わりに配位する。このように 金属イオンの核酸への結合では金属核まわりの配位 構造を無視できない.

さらに有機化学反応においては，有機金属錯体の 配位子の種類や結合様式によって，その反応性，触 媒活性，立体及び部位選択性などが大きく影響を受

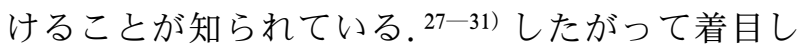
ている金属イオンが触媒金属であった場合, リボザ イム分子による認識様式 (outer-sphere binding 又 は, inner-sphere coordination), 及び金属核の配位 子の種類は金属イオンの触媒能を議論する上で欠く 


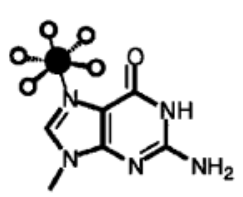

inner-sphere coodination

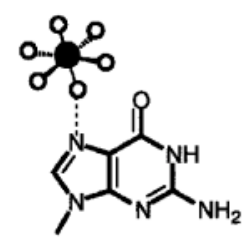

outer-sphere

binding
Metal ion 0 Metal ligand $\left(\mathrm{H}_{2} \mathrm{O}, \mathrm{NH}_{3}\right.$, etc.)

Fig. 2. Two Kinds of Metal Ion-Recognition Modes

The left panel represents inner-sphere coordination and the right panel represents outer-sphere binding [hydrogen bonding through metal ligands] .

ことのできない情報である，現在までにマグネシウ ムイオン，マンガンイオン，コバルトイオンのモ チーフへの結合が結晶学的に確認されており, ${ }^{9-12}$ 速度論解析の結果からはこれらのイオンに加えてカ ルシウムイオン, カドミウムイオンも結合できるこ とが示されている. ${ }^{13-19)}$ HSAB 則 (Hard and Soft, Acid and Base) に沿って考光るとこれらのイオン には硬いルイス酸（Hard Acid）と比較的軟らかい ルイス酸（Soft Acid）のいずれもが含まれている. 硬いルイス酸と軟らかいルイス酸では配位子になり やすい元素が異なるため, 配位化学の観点からも興 味深い.

\section{3. 金属イオンの結合検出法}

NMR は分子量が数千から数万（原子数：数百一 数千）となるような高分子であっても，原理的には 特定の 1 原子に由来するシグナルを検出できる優れ た分光法である. ${ }^{32)}$ したがって生体高分子 (タンパ ク質，核酸など）の局所的な環境を知ることができ る. しかしながら実際の NMR 測定では分子量が大 きくなるとシグナルが広幅化し感度が落ちることに 加えて, 原子数の増加に伴いシグナルが込み合って 帰属が難しくなる。これらの問題からハンマーヘッ ド型リボザイム全残基（分子量約 10000）のシグナ ルの帰属は相当な困難が伴うことが予想される。し たがって生理活性をもつ RNA 分子から機能をもつ たモジュールのみを取り出して低分子量化できれば, NMR 測定上有利となる。 そこで今回の金属イオン 結合モチーフについても, その近傍の配列のみを取 り出してオリゴマー化できるかぞうかを検討した.

金属イオンの認識部位は G10.1 残基の N7 及び
A9 残基のリン酸基に限られることが結晶構造より

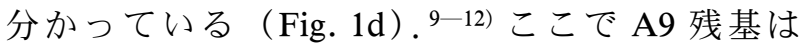
G12 残基と sheared 型の $\mathrm{G}-\mathrm{A}$ 塩基対を形成し，さ らに隣接する G8, A13 も同様に sheared 型の G-A

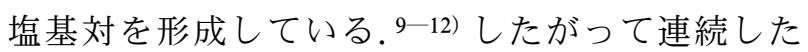
sheared 型 $\mathrm{G}-\mathrm{A}$ 塩基対，及び $\mathrm{G} 10.1$ 残基を含む $\mathrm{C}-$ $\mathrm{G}$ 塩基対を含むような構造モチーフを取り出すこ とができれば金属イオン結合モチーフの活性を損な わず，オリゴマー化できるのではないかと考えた. この要件を満たす RNAオリゴマーとして, r (GGACGAGUCC) ${ }_{2}$ という配列が既に知られてい る(Fig. 1c). 33) この配列を以下, GA10 と呼ぶこ とにする，GA10 は自己相補的に塩基対を組み，二 重らせん中央に連続した sheared 型 G-A 塩基対 と，その両端で $\mathrm{C}-\mathrm{G}$ 塩基対を形成することが分か つている（Fig. 1c).33)したがってこの配列を用い て, 金属イオン結合モチーフと二価金属イオンの相 互作用を調べることとした.

ここで金属イオンは GA10の G7 残基（リボザイ ム中では G10.1 残基）中の N7 に結合すると予想さ れる (Fig. 1)。よって核酸中の窒素原子の NMR シグナルを観測することにより, 金属イオンの結合 をモニターできると考光られる。しかし窒素原子の 中で天然存在比の最も高い安定同位体は ${ }^{14} \mathrm{~N}$ 核で NMR による観測に適した核種ではない，幸いにも 窒素原子には NMR 観測に適したスピン量子数 $(I$ $=1 / 2 ） の{ }^{15} \mathrm{~N}$ 核（天然存在比 $0.3 \%$ ）が存在する. そこで窒素原子を ${ }^{15} \mathrm{~N}$ 核で標識した RNA オリゴ マーを作製し, 結合部位の N7 窒素の ${ }^{15} \mathrm{~N}$ NMR シ グナルを観測することにより金属イオンの結合をモ ニターしようと考えた。 ${ }^{15} \mathrm{~N}$ 核で標識することによ り, 金属イオンの結合が以下の 2 つの方法で検出可 能となる.

1）二価金属イオン源として ${ }^{113} \mathrm{CdCl}_{2}(I=1 / 2)$ を用いると, カドミウムイオンが $\mathrm{N} 7$ 窒素核に直接 配位した場合, ${ }^{15} \mathrm{~N}$ 核と ${ }^{113} \mathrm{Cd}$ 核の間に $J$-カップリ ング $\left({ }^{1} J_{\mathrm{Cd}-\mathrm{N}}\right)$ が観測されることが期待される. ${ }^{34,35)}$ 配位結合は配位共有結合とも言われるくらい，共有 結合性の高い結合だからである，そこで一次元 ${ }^{15} \mathrm{~N}$ NMR スペクトルにより，J-カップリングの検出を 試みる

2）金属イオンが $\mathrm{N} 7$ 窒素核に結合した場合，窒 素原子まわりの環境の変化のため, N7 窒素の化学 
シフト值が変化することが期待される. ${ }^{36,37)}$ そこで 塩化カドミウムによる滴定実験で N7 窒素核の化学 シフト值の変化を追跡する.

そこで GA10 に含まれる 4 つのグアノシン残基 にそれぞれ ${ }^{15} \mathrm{~N}$ 標識グアノシンを導入した 4 種類の RNA オリゴマーを化学合成した.

\section{GA10G1L : r (GGACGAGUCC)}

GA10G2L : r (GGACGAGUCC)

\section{GA10G5L : r (GGACGAGUCC)}

GA10G7L : r (GGACGAGUCC)

配列中，下線で示したグアノシン残基が金属イオン の結合残基で，太字で示したグアノシン残基が安定 同位体標識されたグアノシン残基である。したがつ て配列 GA10G7L が金属イオンの結合を調べるた めの配列で，J-カップリングのデータが得られる 可能性がある. さらに金属イオン結合に伴う, 化学 シフト值変位のデータが得られる。 その他の配列 は，カドミウムイオンの結合とは別の要因による, カドミウムイオン濃度依存的な化学シフト值変位を 知るためのネガティブ・コントロール配列とした。

一般に RNA 分子の調整法としては，化学合成に よる方法と in vitro 転写系を用いる方法の 2 種類が ある. 化学合成の場合, 各残基を一残基毎伸長して いく方法をとるため, 任意の一残基に安定同位体標 識したヌクレオチドを導入することが可能である.

一方，in vitro 転写系では原料として始めに安定同 位体標識したグアノシン三リン酸を加えてしまうた め, すべてのグアノシンが標識されてしまい, 一残 基毎の標識体は作り得ない。すなわち，今実験のサ ンプル調製には化学合成が非常に適した手法である と言える。ところで今回用いた標識グアノシンは残 基内のすべての窒素原子と炭素原子が ${ }^{15} \mathrm{~N},{ }^{13} \mathrm{C}$ 核で 安定同位体標識されたものを用いた。

\section{4. 滴定実験}

今回のサンプルではグアノシン内のすべて窒素原 子が ${ }^{15} \mathrm{~N}$ 標識されているため, 一次元 ${ }^{15} \mathrm{~N}$ NMR ス ペクトル上にグアノシンに含まれる5つの窒素原子 （N1，N2，N3，N7，N9）のシグナルが観測される (Fig. 3). 上記 4 種類の配列について, 種々のカド ミウムイオン濃度で一次元 ${ }^{15} \mathrm{~N}$ NMR スペクトルを 測定して，グアノシン内の全窒素原子の化学シフト 值変位をモニターした。まず，GA10G7L の滴定結 果について述べる. カドミウムイオンの濃度上昇に
伴って, G7 残基の N7 の化学シフト值が大きく高 磁場シフト（-20 ppm）することが分かった（Fig. 3). G7 残基内の他の窒素原子（N1，N2，N3，N9） の化学シフト值に関しては, カドミウムイオン濃度 が上昇してもほとんどシフトせず，G7 残基内の金 属イオン結合部位はN7 であることが分かった (Fig. 3). 次にその他のネガティブ・コントロール 配列の一次元 ${ }^{15} \mathrm{~N}$ NMR スペクトルについても Fig. 3 に示した。ささらこれらの滴定実験の結果を窒素 原子の種類毎（N1，N2，N3，N7，N9）にまとめて各 残基毎の化学シフト值変位としてグラフ化したのが Fig. 4 である.グラフより, 金属イオン結合残基で ある G7 残基の N7 には大きな高磁場シフトが見ら れたが，モチーフ外の $\mathrm{G} 1$ 及び $\mathrm{G} 2$ 残基の N7 のシ グナルはそれほど高磁場シフトしなかった（-5 ppm）（Fig. 4). G5 残基の N7 については金属イオ ン結合に伴って構造変化が誘起され, 若干大きな化 学シフト值変化（-10 ppm）が見られたが，それ でも G7 残基の半分程度であった（Fig. 4)。これら の実験デー夕より, 当初の予想通り金属イオンの結 合残基は $\mathrm{G} 7$ 残基であり，その中でも $\mathrm{N} 7$ 窒素に対 して金属イオンが結合することが分かった。ちなみ に G1, G2, G5 残基の N7 以外の窒素原子の化学シ フト值変位も非常に小さいことが, Fig. 3 及び Fig. 4 より読みとれる.

上記の実験結果より, 次の 2 つの結論が得られ た。まず第 1 に，今回の金属イオン結合モチーフは 溶液中においても金属イオンを結合できる。すなわ ち結晶構造で観測された金属イオンのモチーフへの 結合が，結晶中でのアーティファクトでないことが 証明された。次に, 金属イオンの結合にはハンマー ヘッド型リボザイムの他の保存配列は必要なく，金 属イオン結合モチーフとそれを保持するための二重 らせん構造があればよいことが分かった。すなわち リボザイム中に見られた金属イオン結合モチーフは 独立した機能モジュールであり，他の分子中でも機 能しうると考えられる。例えばリボゾーム RNA （rRNA）の構造中にもこの金属イオン結合モチー フと同様あるいは類似の配列が多数含まれているこ とが報告されており, ${ }^{38)}$ 生理活性を有する RNA 分 子が機能モジュールとして，このモチーフを選んで 用いている可能性が示唆される。 またこれらの部位 では二価金属イオンが RNA に対して結合する可能 
(a)<smiles>Cn1cnc2c(=O)[nH]c(N)nc21</smiles>

(b)

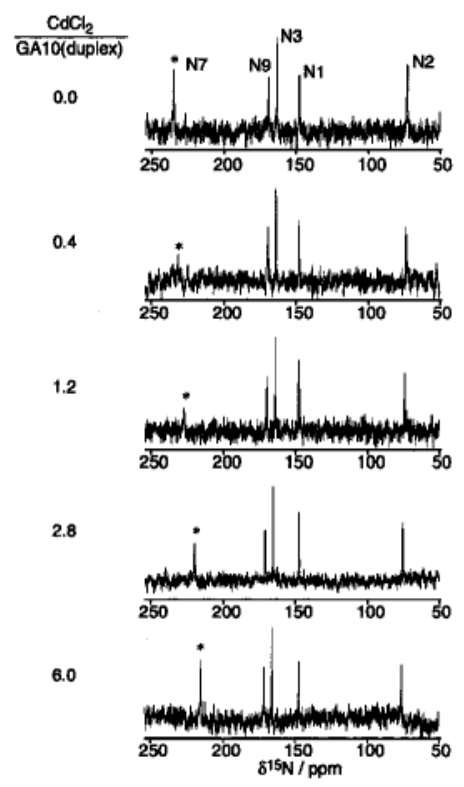

(d)

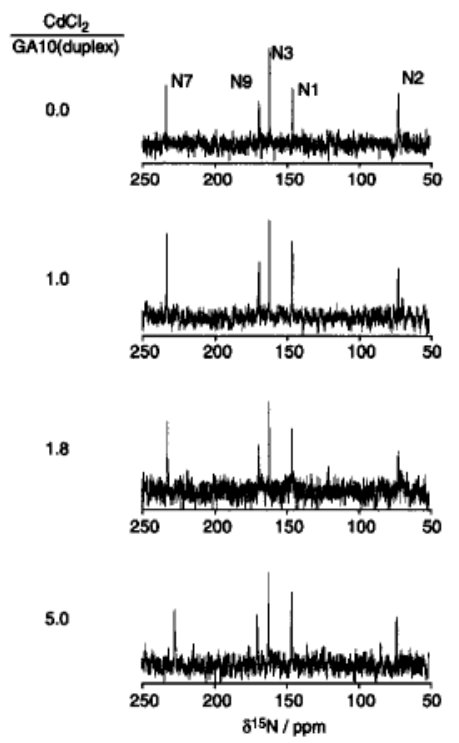

(c)

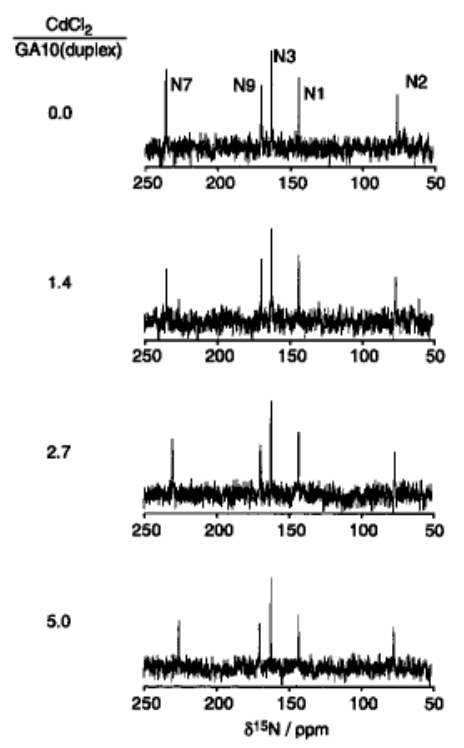

(e)

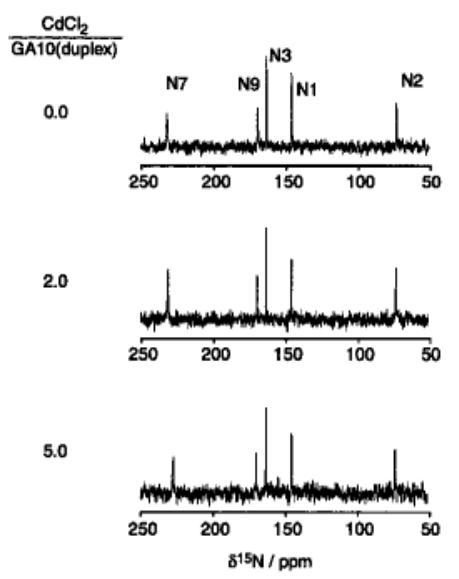

Fig. 3. One-Dimensional (1D) ${ }^{15} \mathrm{~N}-\mathrm{NMR}$ Spectra

(a) Chemical structure of guanosine and numbering system. (b) Titration spectra of GA10G7L (0.9 mm as a single strand). (c) Those of GA10G5L (0.74 mM as a single strand). (d) Those of GA10G2L $\left(0.68 \mathrm{~mm}\right.$ as a single strand). (e) Those of GA10G1L (1.2 mM as a single strand). The ratios of $\left[\mathrm{CdCl}_{2}\right] /[\mathrm{GA} 10$ (duplex) ] are indicated on the left of each spectrum. Resonances are labeled with their names of the nuclei in the spectrum at the top. The resonances of N7 (G7) are labeled with asterisk. The spectrum was recorded at $313 \mathrm{~K}$, with a Bruker DMX800 NMR spectrometer. Typical spectra were recorded with a spectral width of 20000 $\mathrm{Hz}$ digitized into 16384 points $(1.2 \mathrm{~Hz} /$ point and $0.015 \mathrm{ppm} /$ point $)$, and 20000 scans were averaged. These spectra were processed with an exponential window function to give a line-broadening of $10 \mathrm{~Hz}$. 

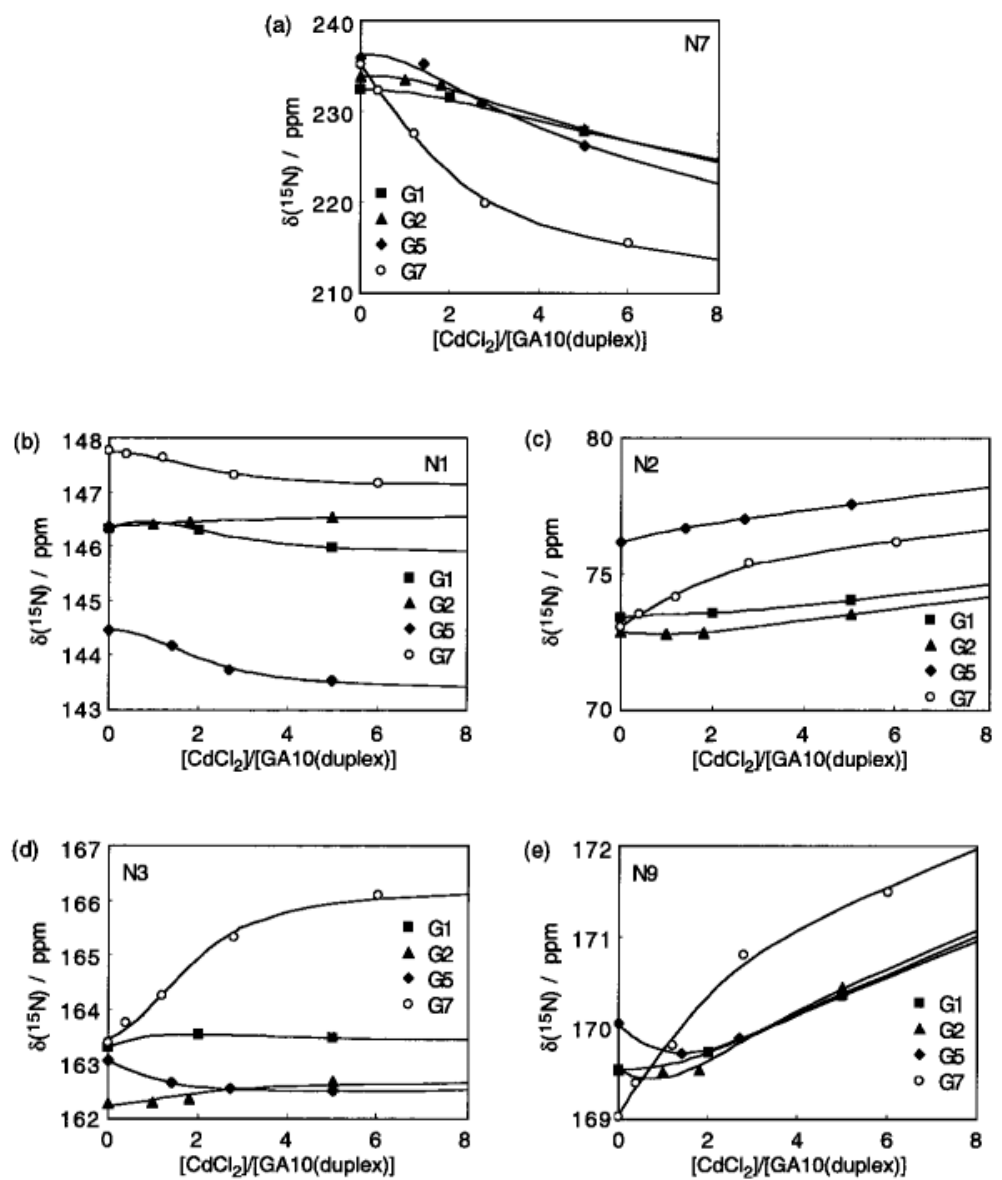

Fig. 4. Plots of ${ }^{15} \mathrm{~N}-$ Chemical Shifts against the Molar Ratio $\left(\left[\mathrm{CdCl}_{2}\right] /[\mathrm{GA} 10\right.$ (duplex) $\left.]\right)$

(a) Those of N7, (b) Those of N1, (c) Those of N2, (d) Those of N3, and (e) Those of N9. Squares, triangles, diamonds and open circles represent corresponding resonances of G1, G2, G5 and G7, respectively. The theoretical curves were generated as described previously. ${ }^{21)}$

Table 1. Summary of ${ }^{15} \mathrm{~N}$ NMR Data

\begin{tabular}{|c|c|c|c|c|c|c|}
\hline Metal ligands & [ligand]/mM & Metals & Res. & $\Delta \delta\left({ }^{15} \mathrm{~N}\right)^{a)} / \mathrm{ppm}$ & $\left.{ }^{1} J_{\mathrm{N}-\mathrm{M}(\mathrm{II})} b\right) / \mathrm{Hz}$ & Ref. \\
\hline $\mathrm{r}(\mathrm{GGACGA} \underline{\mathbf{G U C C}})_{2}[\mathrm{GA} 10]$ & 0.4 & $\mathrm{CdCl}_{2}$ & G7 & $-19.6(6.0 \mathrm{eq})$ & not detected & 5 \\
\hline Guanosine monomer & 500 & $\mathrm{Zn}\left(\mathrm{NO}_{3}\right)_{2}$ & - & $-20.1(1.0 \mathrm{eq})$ & - & 31 \\
\hline Guanosine monomer & 500 & $\mathrm{Hg}\left(\mathrm{NO}_{3}\right)_{2}$ & - & $-20.5(1.0 \mathrm{eq})$ & not reported & 31 \\
\hline Inosine monomer & 1000 & $\mathrm{Zn}\left(\mathrm{NO}_{3}\right)_{2}$ & - & $-15.2(0.7 \mathrm{eq})$ & - & 32 \\
\hline Inosine monomer & 1000 & $\mathrm{Hg}\left(\mathrm{NO}_{3}\right)_{2}$ & - & $-4.8(0.75 \mathrm{eq})$ & not detected & 32 \\
\hline
\end{tabular}

-: not applicable. a) Chemical shift perturbations of N7 (guanosine) from the unmetalated state. Minus and plus values indicate higher and lower field shifts, respectively. b) $J$-coupling between metalated nitrogens $\left({ }^{15} \mathrm{~N}\right)$ and metal ions $(I=1 / 2)$, such as ${ }^{113} \mathrm{Cd}$ and ${ }^{199} \mathrm{Hg}$.

リング $\left({ }^{1} J_{\mathrm{Cd}-\mathrm{N}}\right)$ は観測されなかった（Table 1). このことを単純に解釈すれば，カドミウムイオンは 7 位窒素原子に配位結合はしていないと考えられ る。しかしながら, J-カップリングは速い解離会 合平衡の存在によって見かけ上消失することがあ り，金属イオンの配位環境については慎重に結論し なければならない.
同様の実験として, dimethyl sulfoxide (DMSO) 溶液中でのカドミウムイオンとグアノシン（及びイ ノシン）の NMR による滴定実験のデータがあ る. ${ }^{36,37)}$ 興味深いことにカドミウムーグアノシン/ DMSO 系においても, カドミウムイオンの結合に 伴って, 7 位窒素原子が約 20 ppm の高磁場シフト を起こした (Table 1). さらに, カドミウムと窒素 
原子間の $J$ - カップリング $\left({ }^{1} J_{\mathrm{Cd}-\mathrm{N}}\right)$ は観測されて おらず, ${ }^{36,37)}$ 我々の系と同様の現象を示している (Table 1).ここでカドミウムーグアノシン/DMSO 系におけるカドミウムイオンの結合状態について考 察する。DMSO 溶液中のカドミウムイオンは DMSO 分子によって溶媒和（恐らくスルホキシド 酸素が配位子）されていると考えられる。この時 DMSO 分子には水素結合のプロトン受容基は存在 するがプロトン供与基が存在しない。またカドミウ ムイオンが結合しているグアノシン 7 位窒素原子の まわりにはプロトン受容体のみしか存在しない。し たがってカドミウムイオンがグアノシンに結合する 時に，溶媒を介した結合には適した環境ではないと 言える，裏を返せばカドミウムイオンのグアノシン への結合は配位結合であると考えるのが妥当であ る。その場合， 7 位窒素原子の約 $20 \mathrm{ppm}$ の高磁場 シフトはカドミウムイオンが 7 位窒素原子に結合し たことによると考えられる。同様に，GA10の G7 残基 7 位窒素原子の約 $20 \mathrm{ppm}$ の高磁場シフトはカ ドミウムイオンの $\mathrm{G} 7$ 残基 7 位窒素原子に対する配 位結合によるものと考えられる。この結果は Electron Paramagnetic Resonance（EPR）スペクトル による構造計算の結果 ${ }^{39)}$ とも一致する。また隣接す る 6 位カルボニル酸素原子の配位についても，カル ボニル炭素の ${ }^{13} \mathrm{C}$ NMR 化学シフトの值より検討し た。その結果，化学シフト值には有意な変位が見ら れなかったことから，6位カルボニル酸素はカドミ ウムイオンの配位子ではないと結論した。

またもう 1 つの配位子となる可能性のある，A6 残基（リボザイム中では A9 残基）のリン酸基につ いても結合の有無を一次元 ${ }^{31} \mathrm{P}$ NMR スペクトルに よりモニターした。リン原子の帰属には二次元 ${ }^{1} \mathrm{H}-{ }^{31} \mathrm{P}$ HMQC NOESY スペクトルを用いた（Fig. 5)。カドミウム滴定の結果，結合することが予測さ れる A6 残基のリン酸基に最も大きな高磁場シフト (二本鎖 GA10 に対しカドミウム 10 当量 : 0.86 ppm）が見られた ${ }^{20)}$ 。このことよりカドミウムイオ ンは A6 残基のリン酸基に対しても結合しているこ とが分かった．ただし，この実験のみからはリン酸 の非架橋酸素原子がカドミウムイオンの配位子とな っているかどうかは原理的に結論できない.この点 について，DeRose らのグループは EPR スペクト ルを用いて，リボザイムの金属イオン結合モチーフ (a)

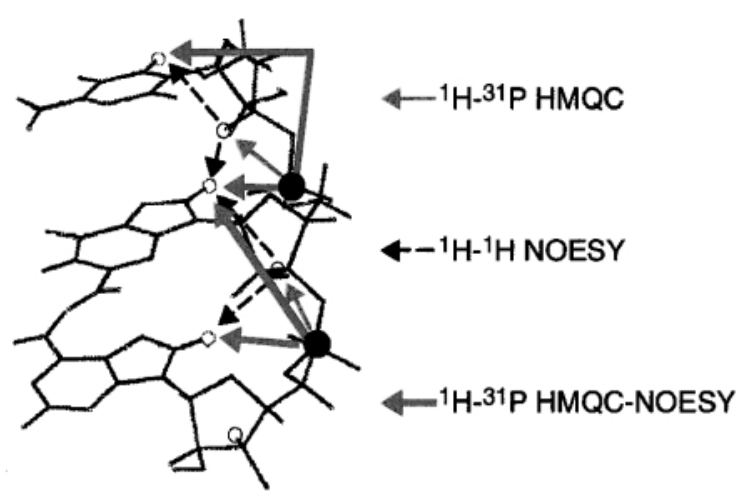

(b)

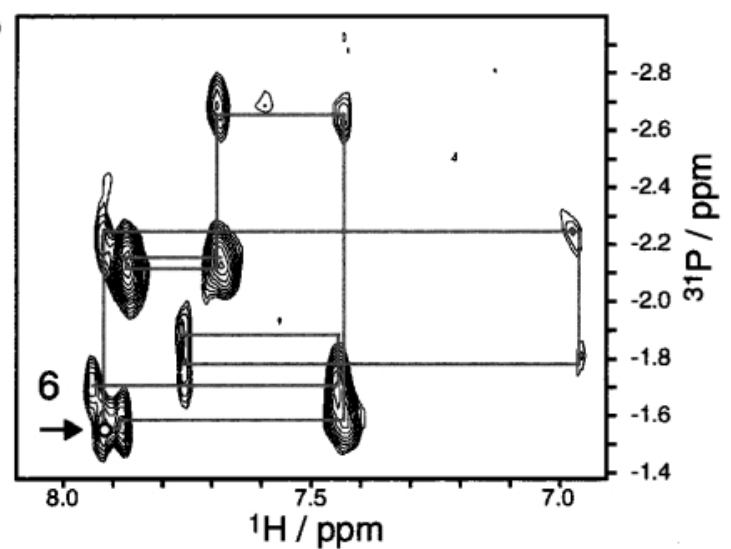

Fig. 5. 2D ${ }^{1} \mathrm{H}-{ }^{31} \mathrm{P}$ HMQC-NOESY Spectrum

(a) Correlations observed in $2 \mathrm{D}^{1} \mathrm{H}^{-31} \mathrm{P}$ HMQC-NOESY spectrum. (b) $2 \mathrm{D}{ }^{1} \mathrm{H}^{-31} \mathrm{P}$ HMQC-NOESY spectrum of GA10. The results of sequential assignments are depicted by gray lines. The cross peaks between $\mathrm{P}(\mathrm{A} 6)$ and $\mathrm{H} 8$ (G5) are depicted as an open circle with an arrow. The spectrum was recorded at $305 \mathrm{~K}$ with a Bruker DMX500 NMR spectrometer. The spectrum was recorded with $1024^{*} 32$ complex points for a spectral width of $5040.32 *$ $404.913 \mathrm{~Hz}, 4096$ scans were averaged, and the mixing time for NOESY was $150 \mathrm{~ms}$.

に対するマンガンイオンの結合をモニターしてい る. 40) その実験によるとリボザイムの A9 残基のリ ン酸基がマンガンイオンの配位子となっていること が示されている.さらにマンガンイオンと，カドミ ウムイオンは HSAB 則上, 比較的ソフトなルイス 酸と分類されており，マンガンイオンで見られた現 象はカドミウムイオンでも同様に起こりうると考え られる。したがって，カドミウムイオンで見られた GA10の A6 残基の ${ }^{31} \mathrm{P}$ NMR シグナルの高磁場シ フトはカドミウムイオンのリン酸基に対する配位と 考えるのが妥当と思われる.

\section{5. おわりに}

以上の結果より, カドミウムイオンはハンマーヘ ッド型リボザイムの金属イオン結合モチーフに対し て, 溶液中でもリン酸基, 7 位窒素原子に対して結 
合することが分かり，いずれも配位子を介さない配 位結合であることが示唆された．さらに金属イオン 結合モチーフは独立した機能モジュールであり，リ ボザイムの他の保存配列なしに金属イオンを結合で きることが分かった．本研究により，カドミウムイ オンの配位子がほぼ同定されたが，このような配位 構造をとつた場合にどのような化学反応を触媒でき るかについて現時点では明らかとなっていない.さ らに，モチーフに結合した金属イオンの役割（構造 金属であるか触媒金属であるか）についても明らか となっておらず，この点を明らかとするための研究 を引き続き行っている，今後もハンマーヘッド型リ ボザイムの RNA 鎖切断に果たす金属イオンの役割 を解析し, 切断反応のメカニズムの全容を解明して いきたいと考えている.

謝辞本研究は私が科学技術特別研究員（科学 技術振興事業団）として，産業技術総合研究所（旧 工業技術院）の多比良和誠教授のもとで行った研究 で, 研究遂行にあたり終始激励, 御助言頂きました ことに御礼申し上げます。 ${ }^{15} \mathrm{~N}$ 標識ヌクレオチド （アミダイト）と NMR のマシンタイムを御供与頂 きました東京都立大学・理学部の甲斐荘正恒先生, 小野晶先生に感謝いたします。また NMR 測定に御 協力頂きました愛媛大学・遺伝子実験施設の森田勇 人先生, 奈良先端科学技術大学院大学の児嶋長次郎 先生, 産業技術総合研究所の山崎和彦博士に感謝い たします。本研究は笠井康博君をはじめとする多比 良研究室の学生及び研究員の方並びに東北大学大学 院・薬学研究科の根東義則教授の御協力により遂行 できたものです，併せて御礼申し上げます。

\section{REFERENCES}

1) Cech T. R., Zaug A. J., Grabowski P. J., Cell, 27, 487-496 (1981).

2) Kruger K., Grabowski P. J., Zaug A. J., Sands J., Gottschling D. E., Cech T. R., Cell, 31, 147-157 (1982).

3) Guerrier-Takada C., Gardiner K., Marsh T., Pace N., Altman S., Cell, 35, 849-857 (1983).

4) Forster A. C., Symons R. H., Cell, 49, 211220 (1987).

5) Buzayan J. M., Hampel A., Bruening G., Nucleic Acids Res., 22, 9729-9743 (1986).
6) Koseki S., Tanabe T., Tani K., Asano S., Shioda T., Shimada T., Nagai Y., Ohkawa J., Taira K., J. Virol., 73, 1868-1877 (1999).

7) Kuwabara T., Warashina M., Orita M., Koseki S., Ohkawa J., Taira K., Nature Biotechnol., 16, 961-965 (1998).

8) Zhou J.-M., Zhou D.-M., Takagi Y., Kasai Y., Inoue A., Baba T., Taira K., Nucleic Acids Res., 30, 2374-2382 (2002).

9) Pley H. W., Flaherty K M., McKay D. B., Nature, 372, 68-74 (1994).

10) Scott W. G., Finch J. T., Klug, A., Cell, 81, 991-1002 (1995).

11) Scott W. G., Murray J. B., Arnold J. R., Stoddard B. L., Klug A., Science, 274, 20652069 (1996).

12) Murray J. B., Terwey D. P., Maloney L., Karpeisky A., Usman N., Beigelman L., Scott W. G., Cell, 92, 665-673 (1998).

13) Peracchi A., Beigelman L., Usman N., Herschlag D. Proc. Natl. Acad. Sci. U.S.A., 93, 11522-11527 (1996).

14) Peracchi A., Beigelman L., Scott E. C., Uhlenbeck O. C., Herschlag D., J. Biol. Chem., 272, 26822-26826 (1997).

15) Scott E. C., Uhlenbeck O. C., Nucleic Acids Res., 27, 479-484 (1999).

16) Wang S., Karbstein K., Peracchi A., Beigelman L., Herschlag D., Biochemistry, 38, 14363-14378 (1999).

17) Yoshinari K., Taira K., Nucleic Acids Res., 28, 1730-1742 (2000).

18) Nakamatsu Y., Warashina M., Kuwabara T., Tanaka Y., Yoshinari K., Taira K., Genes Cells, 5, 603-612 (2000).

19) Murray J. B., Scott W. G., J. Mol. Biol., 296, 33-41 (2000).

20) Tanaka Y., Morita E. H., Hayashi H., Kasai Y., Tanaka T., Taira K., J. Am. Chem. Soc., 122, 11303-11310 (2000).

21) Tanaka Y., Kojima C., Morita E. H., Kasai Y., Yamasaki K., Ono A., Kainosho M., Taira K., J. Am. Chem. Soc., 124, 4595-4601 (2002).

22) Buzayan J. M., van Tol H., Feldstein P. A., Bruening G., Nucleic Acids Res., 18, 44474451 (1990).

23) Ruffner D. E., Uhlenbeck O. C., Nucleic Acids Res., 18, 6025-6029 (1990). 
24) Ruffner D. E., Stormo G. D., Uhlenbeck O. C., Biochemistry, 29, 10695-10702 (1990).

25) Kuimelis R. G., McLaughlin L. W., "Nucleic Acids and Molecular Biology," Vol. 10, ed. by Eckstein F., Lilley D. M. J., 1996, pp. 197215.

26) McKay D. B., $R N A, 2,395-403$ (1996).

27) Uchiyama M., Koike M., Kameda M., Kondo Y., Sakamoto T., J. Am. Chem. Soc., 118, 8733-8734 (1996).

28) Uchiyama M., Kameda M., Mishima O., Yokoyama N., Koike M., Kondo Y., Sakamoto T., J. Am. Chem. Soc., 120, 4934-4946 (1998).

29) Kondo Y., Shilai M., Uchiyama M., Sakamoto T., J. Am. Chem. Soc., 121, 3539-3540 (1999).

30) Imahori T., Uchiyama M., Sakamoto T., Kondo Y., Chem. Commun., 23, 2450-2451 (2001).

31) Uchiyama M., Miyoshi T., Kajihara Y., Sakamoto T., Otani Y., Ohwada T., Kondo Y., J. Am. Chem. Soc., 124, 8514-8515 (2002).

32) Tanaka Y., Kojima C., Yamazaki T., Kodama
T. S., Yasuno K., Miyashita S., Ono A., Ono A., Kainosho M., Kyogoku Y., Biochemistry, 39, 7074-7080 (2000).

33) Katahira M., Kanagawa M., Sato H., Uesugi S., Fujii S., Kohno T., Maeda T., Nucleic Acids Res., 22, 2752-2759 (1994).

34) Damblon C., Prosperi C., Lian L. Y., Barsukov I., Soto R. P., Galleni M., Frere J. M., Roberts G. C. K., J. Am. Chem. Soc., 121, 11575-11576 (1999).

35) Hagen R., Warren J. P., Hunter D. H., Robarts J. D., J. Am. Chem. Soc., 95, 57125716 (1973).

36) Buchanan G. W., Stothers J. B., Can. J. Chem., 60, 787-791 (1982).

37) Buchanan G. W., Bell M. J., Can. J. Chem., 61, 2445-2448 (1983).

38) Gautheret D., Konings D., Gutell R. R., J. Mol. Biol., 242, 1-8 (1994).

39) Morrissey S. R., Horton T. E., Grant C. V., Hoogstraten C. G., Britt R. D., DeRose V. J., J. Am. Chem. Soc., 121, 9215-9218 (1999).

40) Morrissey S. R., Horton T. E., DeRose V. J., J. Am. Chem. Soc., 122, 3473-3481 (2000). 